\title{
Counter-Pandemic Vector of Remote Learning for University Students: Risks and Benefits of Educational Process Large-Scale Digitalization
}

\section{Vector Contrapandémico De Aprendizaje Remoto Para Estudiantes Universitarios: Riesgos Y Beneficios Del Proceso Educativo Digitalización A Gran Escala}

\author{
Olga G. Tavstukha \\ Doctor of Education, Professor of the Department of Preschool, Correctional, Additional Education and Problems of \\ Education, Orenburg State Pedagogical University, Orenburg, Russia. \\ ORCID ID: 0000-0003-1672-3871. \\ Olga M. Osiyanova \\ Doctor of Education, Professor of the Department of English Philology and Methods of Teaching English, Orenburg \\ State University, Orenburg, Russia. \\ Tatiana V. Chelpachenko \\ Doctor of Education, Professor of the Department of pedagogics and sociology, Orenburg State Pedagogical University, \\ Orenburg, Russia. \\ ORCID ID: 0000-0003-3405-0770
}

Anna M. Yudina

$\mathrm{PhD}$ in Education, Associate Professor of the Department of General and Pedagogical Psychology, Vladimir State University named after Alexander Grigoryevich and Nikolai Grigoryevich Stoletov, Vladimir, Russia. ORCID ID: 0000-0001-5420-6643

Oleg M. Ovchinnikov

Doctor of Education, Professor of the Department of Operational and Investigative Activities, Vladimir Law Institute of the Federal Penitentiary Service, Vladimir, Russia. ORCID ID: 0000-0002-6144-1315

Lyudmila P. Illarionova

Doctor of Education, Professor of the Department of Pedagogy, Moscow State Region University, Moscow, Russia.. ORCID ID: 0000-0002-4633-0414

Zelimkhan G. Gereev

Dean of the Faculty of Further Education, Rostov Institute (Branch) of the All-Russian State University of Justice (Russian Law Academy of the Ministry of Justice of Russia), Rostov-on-Don, Russia. ORCID ID: 0000-0003-4206-2253

Natalia S. Aleksandrova

Doctor of Education, Professor of the Department of Pedagogics and Technology of Preschool and Primary Education, Vyatka State University, Kirov, Russia. ORCID ID: 0000-0003-2271-3995

Received 09-08-20 Revised 10-10-20 Accepted 12-12-20 On line 03-12-21

* Correspondence

Email: olgritav@yandex.ru
Citation:

Olga G. Tavstukha, Olga M. Osiyanova, Tatiana V. Chelpachenko, Anna M. Yudina, Oleg M. Ovchinnikov, Lyudmila P. Illarionova, Zelimkhan G. Gereev, Natalia S. Aleksandrova. (2021). Counter-Pandemic Vector of Remote Learning for University Students: Risks and Benefits of Educational Process Large-Scale Digitalization. Propósitos y Representaciones, 9 (SPE3), e1133. Doi: http://dx.doi.org/10.20511/pyr2021.v9nSPE3.1133

(c) Universidad San Ignacio de Loyola, Vicerrectorado de Investigación, 2021. 


\begin{abstract}
The relevance of this study is due to the challenges of the global pandemic, which has led to the large-scale development of education digitalization. In this regard, this article is devoted to revealing the features of remote learning in the context of a global pandemic, identifying the risks and benefits of digital learning. The article reveals the discursive content of the counter-pandemic vector of distance learning for University students; defines the classification of risks and advantages of largescale digitalization of students' remote learning. Based on the results of the study, the authors justified the consolidated model of students distance learning, the counter-pandemic vector of which is a large-scale digitalization of the University educational process. The effectiveness of the model is proved by the results of its use in the process of large-scale digitalization of students' remote learning in the context of a global pandemic. The materials of the article have practical application and can be useful in the development and implementation of digital educational complexes. They are recommended to teachers and students of the University, methodologists, curators, Tutors.
\end{abstract}

Keywords: total pandemic, transformation of the educational process, counter-pandemic vector of remote learning, digitalization of education, risks and benefits, pedagogical monitoring.

\title{
Resumen
}

La relevancia de este estudio se debe a los desafíos de la pandemia global, que ha llevado al desarrollo a gran escala de la digitalización de la educación. En este sentido, este artículo está dedicado a revelar las características del aprendizaje remoto en el contexto de una pandemia global, identificando los riesgos y beneficios del aprendizaje digital. El artículo revela el contenido discursivo del vector antipandémico del aprendizaje a distancia para estudiantes universitarios; define la clasificación de riesgos y ventajas de la digitalización a gran escala del aprendizaje remoto de los estudiantes. A partir de los resultados del estudio, los autores justificaron el modelo consolidado de educación a distancia de los estudiantes, cuyo vector contrapandémico es la digitalización a gran escala del proceso educativo universitario. La eficacia del modelo queda demostrada por los resultados de su uso en el proceso de digitalización a gran escala del aprendizaje remoto de los estudiantes en el contexto de una pandemia mundial. Los materiales del artículo tienen aplicación práctica y pueden ser útiles en el desarrollo e implementación de complejos educativos digitales. Se recomiendan a profesores y estudiantes de la Universidad, metodólogos, curadores, Tutores.

Palabras clave: pandemia total, transformación del proceso educativo, vector antipandémico de aprendizaje remoto, digitalización de la educación, riesgos y beneficios, seguimiento pedagógico.

\section{Introduction}

The study relevance. At the beginning of 2020, for the first time in its history, the world's higher education systems under the influence of the dangers of the global pandemic were transferred to a remote format based on the large-scale digitalization of remote learning. This process is characterized by surprise, instantaneous nature and lack of preparedness for the transition to a qualitatively different format of training (Galiskan et al., 2019; Altbach \& Hans de Wit, 2020; Gafurov et al., 2020; Malikov, Potapova \& Gavrilyuk, 2020). The transition to remote education only in Russia in the academic year 2019/2020 covered more than 4 million students and about 240 thousand teachers ((Shtykhno, Konstantinova \& Gagiev, 2020). Analysis of University practices shows that in a short period, teams of educational institutions have developed and successfully implemented various formats for organizing remote learning, such as asynchronous, synchronous and mixed, based on the principles of interaction between asynchronous and synchronous formats. At the same time, according to the results of this study, there are still trends in the unpreparedness of a number of higher educational institutions for the implementation of innovative remote learning programs in the virtual space (Razumovskaya et al., 2018; Starichenko, 2020; Strokov, 2020). In this regard, this article, as an independent scientific direction, substantiates the theoretical and methodical approach to the development of a consolidated model of remote learning for University students, the counterpandemic vector of which is the large-scale digitalization of the University educational process. In the course of implementing the theoretical and practical foundations for the development of this 
model, pedagogical monitoring is used as the leading research method. The article reveals the discursive content of the counter- pandemic vector of remote learning of University students; the classification of risks and advantages of large-scale digitalization of students' distance learning is determined. Based on the results of the study, the authors of the article substantiate the consolidated model of students' distance learning, the counter-pandemic vector of which is the large-scale digitalization of the University educational process. The effectiveness of the model is proved by the results of its use in the process of large-scale digitalization of students' distance learning in the context of a global pandemic. The materials of the article are focused on the practical application of counter- pandemic complexes of large-scale digitalization of the University educational process. They are recommended to teachers and students of the University, methodologists, curators, Tutors.

\section{Analysis of the Research Problem}

The importance of extraordinary transformations of the University educational process is noted in all works devoted to the problems of overcoming the dangers of the pandemic. The set of studies conducted in the 2019/2020 academic year focuses on the key problem of the educational process large-scale digitalization of distance learning for University students and innovative activities of educational institutions. The research results reflect the priority areas of digitalization corresponding to the dominant remote learning formats in the modern educational process of the University (Mironova et al., 2017; Pushkarev et al., 2019; Altbach \& Hans de Wit, 2020; Gafurov et al., 2020; Malikov, Potapova \& Gavrilyuk, 2020; Rogozin, 2020; Starichenko, 2020; Strokov, 2020; Shtykhno, Konstantinova \& Gagiev, 2020). The analysis of the works established that major groups of researchers justify the benefits of mass digitization of remote educational process of the University in terms of the dangers of the pandemic, but express fears arose against the inequality of universities, due to differences in the provision of educational process with computer equipment and Internet access. For this reason, Regulators of establishing the work of higher education in the context of the pandemic pay special attention to universities that are experiencing temporary difficulties with the transition to a digital format and have not managed to adapt to a new format of education due to the lack of digital infrastructure (Rogozin, 2020; Starichenko, 2020; Strokov, 2020, Kvon et al., 2019; Rudenko et al, 2018). According to experts, the risk of reducing the quality of education is the main danger of mass digitalization of remote learning for students (Bayanova et al., 2020; Digitalization of education in Russia and the world, 2020). In this process, the authors identify three problems that reduce the quality of training: instrumental, creating the need for technical upgrade of home computers of teachers and students; methodical, indicating the need for reformatting of course materials, reload them in the new distance format; psychological, creating limited communication between teachers and students as the main drawback of large-scale digitization development. A significant number of specialists (Gafurov et al., 2020; Malikov, Potapova \& Gavrilyuk, 2020; Rogozin, 2020) see advantages in large-scale digitalization that correlate with improving the quality of education (Orekhovskaya et al., 2019; Rogozin, 2020; Strokov, 2020; Shtykhno, Konstantinova $\&$ Gagiev, 2020). In the course of the study, it was found that despite the active interest of specialists in the large-scale digitalization of remote learning of University students, presented in a significant number of publications, it is premature to talk about a holistic understanding of the transformation of the University educational process based on their use in the face of the dangers and risks of a pandemic. Until now, there are objective conditions and circumstances that require a deep and comprehensive study of all aspects of this extraordinary problem. Therefore, the justification of the theoretical and methodical approach to the development of remote learning consolidated model for University students, the counter-pandemic vector of which is the large-scale digitalization of the educational process of the University, is seen as justified and necessary.

\section{Results and Discussion}

\section{Discursive Content of the Counter-Pandemic Vector of University Students' Remote Learning}

The study identified pedagogical resources of counter-pandemic vector of distance learning of the University students as innovation in controlling the risk spread of a dangerous virus COVID-19 among the students through formats extension of large-scale digitalization of the University educational process. The practical meaning of implementing the counter-pandemic vector of remote 
learning for students at this stage of overcoming the risks of COVID-19 is to create extraordinary conditions for a window of opportunity for using large-scale digitalization of remote learning. It is established that the most important result of the transition to a remote learning format is the indicators of infected with COVID-19 among University students and teachers. They were much lower than the average values of the sick population dynamics in the country. At this stage, these results confirm the effectiveness of the practical implementation of the counter- pandemic vector of distance learning for students. The course of the study established that the priority counter-pandemic vector of University students' remote learning is a large-scale digitalization of the educational process. The results of monitoring this process allow us to formulate preliminary conclusions: today, the main problem of implementing the counter-pandemic vector of large-scale digitalization of distance learning for University students is a decrease in the quality of education due to technical imperfections of teachers' and students' home computers; the lack of reformatted educational materials reloaded into a new remote format; limited access to communication between students and teachers.

\section{Classification of Risks and Benefits of Large-Scale Digitalization of Remote Learning for Students in the Context of a Global Pandemic}

The monitoring study identified groups of risks and advantages of large-scale digitalization in remote learning of students.

Risk groups. They are characterized by a cascade of interaction, permanent nature: from the risks of the short-term perspective (to what extent the student has formed the qualities of overcoming emerging problems)) - to the risks of medium-term prospects (as far the pending risks are minimized) and in the end - to risk of a long-term perspective (to what extent the conditions are developed of remote learning for large-scale digitization and development of the individual student). It is installed that short-term risks of students' remote learning, due to the simultaneous transition to an remote format in the conditions of unpreparedness of the educational environment and living conditions for admission of students in areas of self-isolation, complemented by the imperfection of appropriate tools for communication with the University, teachers and fellow students, pose risks of medium and long term instrumental, methodical and psychological nature. Instrumental risks: they determine the need for technical retrofitting of teachers' and students' home computers; methodical risks determine the need for reformatting of educational materials, reloading them into a new remote format; psychological risks determine the possibility of remote communication between teachers and students.

Groups of advantages of large-scale digitalization, the real significance of which is confirmed by the practical experience of leading universities (Gafurov et al., 2020):

- $\quad$ reformatting of the educational environment from a source of knowledge into fullfledged member of creating new information, which changes the nature of interaction between teacher and student using large-scale digitization in conditions of remote training;

- development of universities' own digital infrastructure with the help of modern equipment: high-speed Internet, local Wi-Fi network, interactive panels in classrooms, local network servers, teachers' laptops, students' tablets and gadgets, etc.;

- $\quad$ reloading students' remote learning with a new generation of software, leading digital platforms for open education, and information systems that provide access to modern educational resources;

Transition to online learning (e learning), which allows you to organize educational activities and online interaction between students and teachers on the basis of large - scale digitalization resources using specialized online services (Zoom, Microsoft, Teams).

\section{Consolidated Model of Remote Learning in the Context of Large-Scale Digitalization of the University Educational Process}

In the course of the study, in order to determine the innovative model of University students' remote learning in the context of large-scale digitalization, a monitoring study of the didactic aspects of the implementation of modern models used in remote educational practice was conducted. Traditional, 
remote learning, mixed and contact models were compared. Based on the results of monitoring, a theoretical and methodical approach to the development of a consolidated model of remote learning for University students is justified, the counter- pandemic vector of which is the large-scale digitalization of the educational process of the University.

Structure and content of the model.

The first level of the model. Theoretical and methodical substantiation of the consolidated model of University students' remote learning, the counter- pandemic vector of which is the largescale digitalization of the educational process of the University. The discursive content, principles, instrumental and methodical content of the model are established, modern orientations of remote learning in the context of the development of large-scale digitalization are determined.

The second level of the model. Organizational and methodical. It presents the composition and structure of reformatted teaching materials on the organization of students' remote training using large-scale digitalization. All didactic processes are carried out using available electronic means in real time: e-mail, website, University pages in social networks, mobile applications, telephone, Fax, Skype, personal requests, automatic notification system.

The third level of the model. Technological. The study finds that the consolidated model as a basic basis uses the principles, structure, content, and technologies of traditional learning, which are implemented in a virtual environment. This difference between the consolidated model and other models allows us to limit the overwhelming dominance of digitalization in the educational process, at least for this perspective.

The fourth level of the model. Instrumental. The implementation of the consolidated model can be carried out based on different platforms that provide opportunities for students to participate in various types of active learning activities on the sites of webinars, lectures, video conferences, chats. Training activities at these remote sites can be carried out in an online format with the help of online training materials prepared by the teacher.

\section{Conclusion}

The study conducted confirms the theoretical and practical significance of the problem of studying remote learning of University students in the context of large-scale digitalization of the educational process as an independent scientific direction determined by the dangerous conditions of the global pandemic. Based on the results of monitoring the processes of large-scale digitalization of distance learning in the practical activities of universities in the context of a global pandemic, a counterpandemic vector is established that permanently expands the remote learning format, requiring the intensification of new approaches to its large-scale digitalization. In this regard, the article as an independent scientific direction justifies the theoretical and methodical approach to the development of a consolidated model of remote learning for University students, the counter- pandemic vector of which is the large-scale digitalization of the educational process of the University. To implement the theoretical and practical bases for the development of this model, pedagogical monitoring was used as the leading research method.

The article reveals:

1) Discursive content of the counter-pandemic vector of University students distance learning;

2) Classification of risks and advantages of large-scale digitalization of students' distance learning is defined;

3) Based on the results of the study, the authors of the article substantiate the consolidated model of students' remote learning, the counter-pandemic vector of which is the large-scale digitalization of the University educational process. The effectiveness of the model is proved by the results of its use in the process of large-scale digitalization of students' remote learning in the context of a global pandemic. This problem as an independent scientific direction does not exhaust itself by solving the tasks set. Technologies of students' independent work in the conditions of a new educational environment caused by large-scale digitalization deserve special attention in the process 
of research continuing.

\section{References}

Altbach, F.J., Hans de Wit. (2020). Information technology in the context of COVID-19: a turning point? International higher education, 103, 6-8.

Bayanova, A.R., Sivova, I.V., Kamasheva, Y.L., Popova, O.V., Semyanov, E.V., Shagieva, R.V., Yusupov, I.M. (2020). Student online services consumption: Routine practices or mistrust to digital service? Contemporary Educational Technology, 11(1), 47-54.

Caliskan, S., Guney, Z., Sakhieva, R.G., Vasbieva, D.G., \& Zaitseva, N.A. (2019). Teachers' Views on the Availability of Web 2.0 Tools in Education. International journal of emerging technologies in learning, 14(22), 70-81.

Digitalization of education in Russia and the world. (2020). URL: https://akvobr.ru/cifrovizaciya_obrazovaniya_v_rossii_i_mire.html (date accessed 20.04.2020)

Gafurov, I.R., Ibragimov, G.I., Kalimullin, A.M. \& Alishev, T.B. (2020). Transformation of higher education during the pandemic: pain points. Higher education in Russia, 10, 101-112. Moscow.

Kvon, G.M., Vaks, V.B., Kalimullin, A.M., Bayanova, A.R., Shaidullina, A.R., Dolzhikova, A.V. \& Lapidus, N.I. (2019). Developing the Informational and Digital Environment of a University: Problem Analysis and Assessment. Eurasia Journal of Mathematics, Science and Technology Education, 15(10), 1841-1848. URL: https://kpfu.ru/staff_files/F1126799205/Developing_the.pdf

Malikov, A.V., Potapova, I.I. \& Gavrilyuk, E.S. (2020). Adapting University faculty to the challenges of the digital economy. Journal of creative economy, 14(6), 1011-1020. Moscow.

Mironova, M.D., Zaitseva, N.A., Larionova, A.A., Akhpolova, V.B., Glagoleva, L.E., Belozerova, J.M. (2017). Features of Innovative Personnel Management of Service Companies in the Period of Implementation of Organizational Changes. Eurasian journal of analytical chemistry. 12(5B), 793-802.

Orekhovskaya, N.A., Chistyakov, A.A., Kryukova, N.I., Krokhina, J.A., Ospennikov, Y.V., \& Makarova, E.V. (2019). Orthodoxy and Modernity their Contact Facets in Russian Society. European Journal of Science and Theology, 15(2), 67-77.

Pushkarev, V.V., Cherdymova, E.I., Prokopyev, A.I., Kochurov, M.G., Shamanin, N.V., Ezhov, S.G., Kamenskaya, S.V., \& Kargina, N.V. (2019). Motivation and needs in the area of the spouses with different experiences of cohabitation. Dilemas contemporáneos: Educación, Política y Valores, VI (Special Edition), Article No: 41.

Razumovskaya, M.I., Larionova, A.A., Zaitseva, N.A., Orekhov, V.D., Trufanova, S.N., Korzhanova, A.A., \& Takhumova, O. (2018). Modeling the network integration space for educational programs. Modern journal of language teaching methods, 8(5), 56-67.

Rogozin, D.M. (2020). Teachers of Russian universities on the development of the online environment in the context of the pandemic. Monitoring the economic situation in Russia: trends and challenges of socio-economic development, 14(16), $36-44$. .

Rudenko, L.G., Larionova, A.A., Zaitseva, N.A., Kostryukova, O.N., Bykasova, E.V., Garifullina, R.Z., Safin, F.M. (2018). Conceptual model of training personnel for small business services in the digital economy. Modern journal of language teaching methods, 8(5), 283-296.

Shtykhno, D.A., Konstantinova, L.V. \& Gagiev, N.N. (2020). Transition of universities to remote mode during the pandemic: problems and possible risks. Open education, 24(5), 72-79. Moscow.

Starichenko, B.E. (2020). Digitalization of education: illusions and expectations. Pedagogical education in Russia, 3, 49-58. Yekaterinburg.

Strokov, A.A. (2020). Digitalization of education: problems and prospects. Bulletin of Minin University, 8(2), 1-15. 